\title{
Correction to: Habitat fragmentation and forest management alter woody plant communities in a Central European beech forest landscape
}

\author{
Kevin Wilhelm Bähner ${ }^{1}$ D $\cdot$ Marcelo Tabarelli $^{2}$ (D) Burkhard Büdel $^{1}$ (D) Rainer Wirth $^{1}$ (D)
}

Published online: 12 October 2021

(c) The Author(s) 2021

\section{Correction to: Biodiversity and Conservation (2020) 29:2729-2747 https://doi.org/10.1007/s10531-020-01996-6}

The article: "Habitat fragmentation and forest management alter woody plant communities in a Central European beech forest landscape", written by Kevin Wilhelm Ba“hner, Marcelo Tabarelli, Burkhard Bu" del and Rainer Wirth, was originally published electronically on the publisher's internet portal on 28 May 2020 without open access. With the author(s)' decision to opt for Open Choice the copyright of the article changed on 14 October 2021 to (The Author(s) 2021 and the article is forthwith distributed under a Creative Commons Attribution 4.0 International License, which permits use, sharing, adaptation, distribution and reproduction in any medium or format, as long as you give appropriate credit to the original author(s) and the source, provide a link to the Creative Commons licence, and indicate if changes were made. The images or other third party material in this article are included in the article's Creative Commons licence, unless indicated otherwise in a credit line to the material. If material is not included in the article's Creative Commons licence and your intended use is not permitted by statutory regulation or exceeds the permitted use, you will need to obtain permission directly from the copyright holder. To view a copy of

The original article can be found online at https://doi.org/10.1007/s10531-020-01996-6.

Rainer Wirth

wirth@rhrk.uni-kl.de

Kevin Wilhelm Bähner

kevin.baehner@gmx.de

Marcelo Tabarelli

mtrelli@ufpe.br

Burkhard Büdel

buedel@rhrk.uni-kl.de

1 Plant Ecology and Systematics, University of Kaiserslautern, Erwin-Schrödinger-Straße, 67663 Kaiserslautern, Germany

2 Departamento de Botânica, Universidade Federal de Pernambuco, Av. Prof. Moraes Rego, s/n, Cidade Universitária, Recife, PE 50670-901, Brazil 
this licence, visit http://creativecommons.org/licenses/by/4.0/. The original article has been corrected.

Open Access This article is licensed under a Creative Commons Attribution 4.0 International License, which permits use, sharing, adaptation, distribution and reproduction in any medium or format, as long as you give appropriate credit to the original author(s) and the source, provide a link to the Creative Commons licence, and indicate if changes were made. The images or other third party material in this article are included in the article's Creative Commons licence, unless indicated otherwise in a credit line to the material. If material is not included in the article's Creative Commons licence and your intended use is not permitted by statutory regulation or exceeds the permitted use, you will need to obtain permission directly from the copyright holder. To view a copy of this licence, visit http://creativecommons.org/licenses/by/4.0/.

Publisher's Note Springer Nature remains neutral with regard to jurisdictional claims in published maps and institutional affiliations. 